\title{
JĘZYKOWO-KULTUROWY OBRAZ CZASU OPARTY NA METAFORYCE CYKLU DOBOWEGO I ROCZNEGO UTRWALONY W INSKRYPCJACH NAGROBNYCH CMENTARZY WIEJSKICH (NA PRZYKŁadZIE Wybranych wsI PodKarpacia I MaŁopolski)
}

Wszystko ma swój czas, i jest wyznaczona godzina na wszystkie sprawy pod niebem. Jest czas rodzenia i czas umierania, czas sadzenia i czas wyrywania tego, co zasadzono

— takie słowa czytamy w biblijnej Księdze Koheleta (Koh 3, 1-2). Ta odwieczna prawda, włożona w usta biblijnego mędrca, wyraża uniwersalną myśl dotyczącą przemijania. Jej wartość jest jednak podwójna. Poza faktem, że nic nie dzieje się przypadkowo, ale postępuje według określonego, Bożego porządku, co wyznacza zmienność ludzkiej egzystencji, cytowane słowa wskazują na etapy, swoiste kamienie milowe, wyznaczające rytm życia. Jego nieodłączne, można by rzec: skrajne elementy — narodziny oraz śmierć - tworzą spinającą je klamrę. W kontekście rozważań na temat językowego obrazu czasu ${ }^{1}$ odgrywają one niemałą rolę, gdyż wskazują na jego szczególny odcinek, jakim jest życie człowieka ${ }^{2}$. Nieco inny charakter posiadają dwa kolejne wyznaczniki Bożego planu, jakimi są: pora zasiewu oraz pora zbiorów. W przeciwieństwie do omówionych terminów łatwo zauważyć ich powtarzalność i regularność. Ich suma tworzy wpisany w naturę cykl roczny, a więc konstytuuje porządek odnawialny i uniwersalny. Realizuje on jeszcze inną koncepcję wspomnianego pojęcia, który w podanym znaczeniu można sprowadzić do określeń: „chwila”, „moment”3.

Choć słowa Księgi Koheleta odmiennie konceptualizują pojęcie czasu, istnieją teksty, które wykorzystują oba rozumienia analizowanego terminu. Są nimi inskrypcje

\footnotetext{
* Małgorzata Herchel - autorka rozprawy doktorskiej na temat inskrypcji nagrobnych, napisanej pod kierunkiem prof. dr hab. Haliny Kurek w Katedrze Lingwistyki Kulturowej i Socjolingwistyki Uniwersytetu Jagiellońskiego (2011); uczestniczka kilku konferencji naukowych (m.in. w Krakowie, Ostrołęce, Gnieźnie, Rzeszowie); jej zainteresowania naukowe obejmują etnolingwistykę, epigrafikę nagrobną, pieśni pogrzebowe i literaturę ludową.

${ }^{1}$ Za J. Bartmińskim przyjmuje się, że pod pojęciem językowego obrazu świata kryje się odzwierciedlona na poziomie języka, różnorodnie zwerbalizowana interpretacja rzeczywistości, którą da się ująć „w postaci sądów o świecie" (J. Bartmiński, O pojęciu jezykowego obrazu świata, [w:] tenże, Jezykowe podstawy obrazu świata, Lublin 2007, s. 12).
}

${ }^{2}$ A. B. Burzyńska, A. Libura, Obraz czasu w języku potocznym i naukowym, [w:] Język a Kultura, red. A. Dąbrowska, J. Anusiewicz, t. 13, Wrocław 2000, s. 134.

${ }^{3}$ Tamże, s. 134; zob. także: Stownik jezzyka polskiego, red. M. Szymczak, t. 1, Warszawa 1978, s. 330. 
nagrobne, nieodłącznie związane z pojęciem śmierci. Warto również zauważyć, że zaskakująco wysoką frekwencję posiadają epitafia, które posługują się metaforyką opartą na nawiązaniach do cyklu rocznego lub w mniejszym zakresie - do cyklu dobowego.

Obecne studium stanowi próbę rekonstrukcji obrazu zakrzepłego w inskrypcjach nagrobnych czasu ${ }^{4}$, który istotnie modelowany jest przez odwołanie do wspomnianej metaforyki. Wynika on z analizy bogatego, bo liczącego ponad 7000 tysięcy nagrobków zbioru, zgromadzonego w czasie badań terenowych w latach 2004-2010. Ponieważ cytowane epitafia pochodzą z cmentarzy wiejskich, w opracowaniu będzie mowa o językowo-kulturowym obrazie świata.

Najmniejszą uchwytną i naturalną, a więc wynikającą z odwiecznego porządku świata, jednostką czasu, o której mowa w epitafiach, jest rytm dobowy. W kulturze ludowej porządek ten stanowi swoistą ramę temporalną, określającą czas aktywności człowieka. Zgodnie z powszechnym wyobrażeniem oraz odwiecznym prawem natury praca powinna rozciągać się między wschodem i zachodem słońca. Dotyczy to zwłaszcza prac polowych. Wedle światopoglądu przedstawicieli kultury tradycyjnej, jakakolwiek działalność podejmowana po zmroku uważana była za herezję, ponieważ stanowiła zaburzenie naturalnego porządku. Ten sposób myślenia pogłębia opozycję pomiędzy światłem i ciemnością jako dwoma przeciwstawnymi jakościami: czasem dla człowieka pomyślnym (dniem) oraz czasem niepomyślnym (noca), co dodatkowo potęguje przekonanie, że światło to siła twórcza, natomiast ciemność — siła destrukcyjna ${ }^{5}$. Opozycja „światło” : „ciemnośc”, charakterystyczna dla kultury ludowej, oznacza jednak nie tylko strukturę solarną, ale także konstrukcję funeralną, kontrastującą życie i śmierć. Podstawą tej konotacji jest przekonanie, że pogrążenie się w nocy jest równoznaczne z unicestwieniem bytu, a przez to stanowi synonim śmierci ${ }^{6}$. Zgon oznacza w takim kontekście przejście ze światła do ciemności, opuszczenie dnia oraz pogrążenie się w mrokach nocy. Dodatkowo opozycję tę może wzmacniać symbolika życia jako drogi, tułaczki, prowadząca do analogii: koniec drogi — koniec życia. Widoczne jest to w cytowanym poniżej epitafium, stanowiącym fragment popularnej pieśni pogrzebowej:

Tułaczka moja już dobiegła kresu

Dla moich oczu słońce ziemi zgasło

Dziś moją duszę w ręce Twe powierzam

Mój Stworzycielu i najlepszy Ojcze ${ }^{7}$

(Trzęsówka, pow. kolbuszowski)

Opozycja pomiędzy światłem i ciemnością, odwołująca się do metaforyki solarnej, może również sygnalizować anomalie zachodzące w świecie przyrody. Tego typu na-

\footnotetext{
${ }^{4}$ Pojęć: inskrypcja nagrobna, epitafium, nagrobek, napis nagrobny używam wymiennie na zasadzie synonimii ze względów stylistycznych.

${ }^{5}$ A. Brzozowska-Krajka, Symbolika dobowego cyklu powszedniego w polskim folklorze tradycyjnym, Lublin 1994, s. 16-18.

${ }^{6}$ Tamże, s. 37.

${ }^{7}$ Wszystkie epitafia przywołuje się w ich oryginalnym brzmieniu.
} 
grobki informują, że śmierć nastąpiła się wbrew istniejącemu, postrzeganemu w kulturze ludowej jako święty, rytmowi natury. Realizacje takich metafor wskazują na przedwczesne nastanie nocy:

Nim słońce zaszło

Dla mnie nastała noc

(Zgórsko, pow. mielecki)

Zaszło mi słońce

Gdy był jeszcze dzień

(Cmolas, pow. kolbuszowski; Trzęsówka, pow. kolbuszowski)

Konstatacja oddająca niezgodny z rytmem natury zachód słońca może bezpośrednio wskazywać na przedwczesny zgon, co widoczne jest w następującym epitafium:

Odszedłeś od nas synu

Tak niespodziewanie, choć było za wcześnie

I słońce ci zgasło, chociaż dzień był jeszcze

(Biórków Wielki, pow. proszowicki)

Metaforyka światła pojawia się także w epitafiach posługujących się symboliką życia jako płomienia. W takim kontekście oznacza on wewnętrzny czynnik ożywiający człowieka, siły witalne warunkujące jego istnienie. Zgodnie z tą analogią śmierć symbolizowana jest przez jego zgaśnięcie czego odzwierciedlenie stanowią obecne w języku konstrukcje oznaczające zgon: „czyjeś życie gaśnie”, „gasnąć w oczach” oraz utrwalone w inskrypcjach metafory:

O Boże zgasł płomień

Życia naszego

(Gawłuszowice, pow. mielecki)

Stosunkowo popularnym sposobem mówienia o śmierci, odwołującym się do symboliki światła, jest również metafora zgaśnięcia jako substytutu zgonu. Realizacja tej przenośni polega na zastąpieniu czasownika umrzeć oddającym ten fakt czasownikiem „zgasnąç", który w strukturach składniowych łączy się z podmiotem oznaczającym zmarłego. Tego typu konstrukcje pojawiają się sporadycznie w onomastycznej ${ }^{9}$ części inskrypcji:

\footnotetext{
${ }^{8}$ Zob. A. Krzyżanowska, Polska i francuska frazeologia śmierci, Lublin 1999, s. 69.

${ }^{9}$ Podstawę stanowi tu klasyfikacja Kazimierza Długosza, który wyróżnił następujące typy inskrypcji: 1. Inskrypcje onomastyczne — stanowiące niejako odpowiedź na pytania: „kto? kiedy urodził się? kiedy umarł?”, a więc zawierające jedynie imię i nazwisko zmarłego, datę jego urodzenia oraz datę śmierci, 2. Inskrypcje onomastyczno-tekstowe - napisy dwuczłonowe, poszerzające informacje podane w epitafium onomastycznym o tekst, zwykle poetycki, 3. inskrypcje trójczłonowe - eksponujące dodatkowo także nadawcę inskrypcji (zob. K. Długosz, Inskrypcje nagrobne Pomorza Zachodniego w ujęciu jezzykoznawczym, Szczecin 1991, s. 23-24).
} 


\author{
Zgasła d. 30 stycznia \\ 1886. \\ (Zgórsko, pow. mielecki) \\ Zgasła w drugiej \\ Wiośnie życia \\ (Przebendów, pow. mielecki)
}

Najczęściej jednak ich obecność potwierdza część tekstowa. Epitafia posługujące się metaforą śmierci jako zgaśnięcia wskazują na zgon nagły i przedwczesny. Zawierające je inskrypcje informują o śmierci dziecka i najczęściej wyrażają żal rodziny, wynikający z niemożności radowania się wspólnym życiem:

\footnotetext{
Niecały rok przeżyliśmy

Z sobą byłaś nam

Szczęściem z życia ozdobą

Zgasłaś by lata przepłakać

Za tobą

(Rożnowice, pow. gorlicki)
}

Zazwyczaj spotykane w epitafiach metafory śmierci jako zgaśnięcia płomienia życia opierają się na analogii pomiędzy zmarłym a naturalnym źródłem światła. Wśród nich największą frekwencję posiada słońce, co pozostaje w ścisłym związku z ludową wizją świata. Słońce, stanowiące w kulturze ludowej jakość temporalną, określające czas aktywności człowieka oraz wartościowane przez nią zdecydowanie pozytywnie, wyznacza w epitafiach paradygmat życia i śmierci. W ten sposób cykl dobowy, będący interwałem między pojawieniem się i zniknięciem słońca w dwóch różnych punktach horyzontu $^{10}$, staje się metaforą ludzkiej egzystencji oraz umierania ${ }^{11}$. Przenośnia ta wynika ze skojarzenia faktu zgonu (czyli odejścia, zniknięcia zmarłego) z zachodem słońca i konceptualizowana jest przy pomocy czasownika „zgasnąc”, czego rezultatem są obecne w nagrobkach struktury „zgasnąc jak słońce/zgasnąć jak promień słońca”:

Znikliście nam kochani

Jak płomyk słońca

Nam pozostała boleść bez końca

(Gawłuszowice, pow. mielecki)

Synonimem światła słonecznego jest również światło dzienne, co wynika z roli słońca w dualistycznej koncepcji życia i śmierci. Symbolizuje ono dzień, a więc czas pracy i życia:

A Ty, Aleksandrze, coś z Najwyższej Mocy

Zgasł jako światło dzienne wśród ponurej nocy,

${ }^{10}$ A. Brzozowska-Krajka, $d z . c y t .$, s. 14.

${ }^{11}$ Takie znaczenie odnajdujemy także w Stowniku symboli W. Kopalińskiego (Warszawa 1990, s. 388-389). 
Wierzę, że żal Twej matki po on czas się skończy,

Jak się jej duch z Twoim w drugim świecie złączy.

(Uście Solne, pow. brzeski)

Bywa, że metafora solarna zostaje wzmocniona innymi metaforami śmierci. Towarzyszące im obrazy wprowadzane są na zasadzie przyległości semantycznej: łączy je przynależność do świata przyrody oraz fakt nazywania zjawisk meteorologicznych:

Zgasłeś jak słońce zniknąłeś

Jak mgły a nam pozostał smutek, łzy

(Babice, pow. przemyski)
Świeciłeś jak słońce
Zgasłeś jak zorza
Bóg cię powołał
Taka była wola Boża
(Faliszewice, pow. tarnowski)

Nieco rzadziej pojawiają się w epitafiach metafory ukazujące zmarłego jako gwiazdę. Ich rodowodu upatrywać należy w literaturze starożytnej, która spopularyzowała wizję przemiany umierającego $\mathrm{w}$ to źródło światła ${ }^{12}$. Proweniencje tego skojarzenia tkwią również w astrologii oraz kulturze ludowej. Według wierzeń społeczności tradycyjnej, każdy człowiek posiada swoją gwiazdę, która zapala się w momencie jego narodzin, a gaśnie (lub nawet spada ${ }^{13}$ ) w chwili śmierci, co potwierdza „powiedzenie urodzić się pod szczęśliwą gwiazdą"14. Świadectwo tego przekonania odnajdujemy w następującym epitafium:

Krótko wasza gwiazdka świeciła,

Lecz taka wola Boża była.

(Paleśnica, pow. tarnowski)

Według przekonań członków społeczności tradycyjnej, jej rozmiar jest proporcjonalny do wieku człowieka - gwiazda dziecka posiada niewielkie rozmiary, jednak powiększa się wraz z jego wzrostem. Związek istoty ludzkiej i wspomnianych ciał niebieskich podkreśla także ludowe przekonanie dotyczące intensywności ich światła. Zgodnie z nim jest ono słabsze, gdy człowiek jest chory lub źle mu się powodzi, moc-

\footnotetext{
${ }^{12} \mathrm{~J}$. Kolbuszewski, Wiersze z cmentarza. O wspótczesnej epigrafice wierszowanej, Wrocław 1985, s. 177.

${ }^{13} \mathrm{~J}$. Bartmiński, „Niebo się wstydzi”. Wokót ludowego pojmowania ładu świata, [w:] Stereotypy mieszkaja $w$ jezzyku. Studia etnolingwistyczne, red. B. Paprocka, Lublin 2007, s. 136; S. Niebrzegowska, Każdy człowiek ma swoja gwiazdę, „Twórczość Ludowa” R. 9: 1994, nr 3-4 (26), s. 7-8. Abstrahując od symboliki gwiazdy, należy podkreślić, że sam ruch skierowany w dół, czyli spadanie, jest w kulturze ludowej pojmowany jako śmierć (zob. W. Pawluczuk, Obrazświata w kulturze ludowej, [w:] Z problemów badania kultury ludowej, red T. Kłak, Katowice 1988, s. 7, S. Niebrzegowska, dz. cyt., s. 7).

${ }_{14}$ Zob. O. Kolberg, Dzieła wszystkie, t. 7: Krakowskie, cz. 3, Wrocław-Poznań 1962 (reprint), s. 31;

O. Kolberg, Dzieła wszystkie, t. 17: Lubelskie, cz. 2, Wrocław-Poznań 1962 (reprint), s. 71.
} 
niejsze — gdy jest zdrowy i szczęśliwy. Symbolika gwiazd jako świateł ludzkiego życia implikuje określone zachowania, które wśród społeczności tradycyjnej postrzegane są jako swoiste normy postępowania. Wiąże się z nimi zakaz pokazywania ich palcem oraz patrzenia na nie, ponieważ są to gesty sprowadzające rychłą śmierć. Ujrzenie ich $\mathrm{w}$ momencie, kiedy spadają, winno skutkować pacierzem zmówionym w intencji człowieka, który właśnie zmarł15.

Echa tego światopoglądu są obecne w inskrypcjach w postaci metafory gasnącej gwiazdy, oznaczającej kres ludzkiego życia na ziemi ${ }^{16}$. Badacze epigrafiki nagrobnej podkreślają, że nagrobki posługujące się tą metaforą tworzą dość osobliwy, zazwyczaj pozbawiony logiki układ, co prezentuje następujące epitafium:

\author{
Zgasłeś jak gwiazdka \\ na niebios błękicie \\ pozostawiając żal i smu- \\ tek na całe życie \\ (Grywałd, pow. nowotarski)
}

Sprzeczna z logiką konstrukcja, wyrażona w dwóch pierwszych wersach przywołanego epitafium, wynika z faktu, iż gasnąca na błękicie nieba gwiazda zostaje przyćmiona przez światło słoneczne. Decyduje o tym użycie rzeczownika oznaczającego barwę nieba, który jednoznacznie wskazuje na to, że zgaśnięcie wspomnianego ciała niebieskiego towarzyszy światłu dziennemu. W rezultacie nabieramy przekonania, że śmierć konceptualizowana jest wyłącznie przez obraz gwiazdy, która stanowi nośnik istotnych znaczeń. Pozostała część inskrypcji stanowi jedynie swoisty dodatek pełniący funkcję dekoracyjną ${ }^{17}$. Bardziej uzasadniona z punktu widzenia logiki wydaje się następująca konstrukcja:

\author{
Zgasłeś synu \\ Jak gwiazda na niebie \\ A nam jest smutno \\ I tęskno bez ciebie \\ (Biórków Wielki, pow. proszowicki)
}

Naturalistyczna koncepcja życia ludzkiego, którego ramy stanowi cykl dobowy, posiada swą realizację także $\mathrm{w}$ inskrypcjach przywołujących poszczególne etapy dnia. Ich obecność w języku oddają popularne metafory: „poranek życia” (młodość), „wieczór życia" (starość), a swoistym regulatorem owego rytmu jest słońce ${ }^{18}$. W epitafiach

${ }^{15}$ S. Niebrzegowska, Gwiazdy w ludowym językowym obrazie świata, [w:] Językowy obraz świata, red. J. Bartmiński, Lublin 2004, s. 140. Przekonanie takie potwierdzają również badania Oskara Kolberga prowadzone w różnych miejscach Polski (zob. O. Kolberg, Dzieła wszystkie, t. 7: Krakowskie, , s. 31-32; O. Kolberg, Dzieła wszystkie, t. 48: Tarnowskie-Rzeszowskie, Wrocław-Poznań 1967, s. 259).

${ }^{16}$ I. Borkowski, Śmierci tajemnicze wrota. Językowy świat inskrypcji nagrobnych, [w:] Jezzyk a Kultura, s. 349.

${ }^{17}$ J. Kolbuszewski, dz. cyt., s. 178.

${ }^{18} \mathrm{~K}$. Moszyński stwierdza, że w kulturze słowiańskiej cykl dobowy pełnił rolę swoistego regulatora życia ludzkiego, a światło słoneczne określało miary czasu. Na podstawie ruchu Słońca w słowiańszczyźnie 
bywają one uzupełniane o kolejne ogniwo powstałe na zasadzie konotacji. Jej rezultat, oparty na łańcuchu przyczynowo-skutkowym, prezentuje się następująco: starość $\rightarrow$ śmierć, wieczór $\rightarrow$ noc. Relację tę realizuje przywołane poniżej epitafium, w którym metaforę śmierci werbalizuje zwrot „przejść na drugi brzeg”:

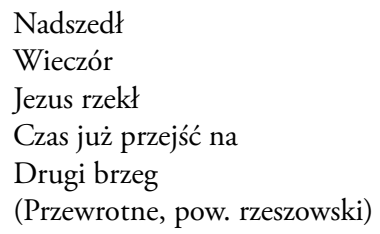

Na planie szerszym rytm życia ludzkiego podlega paradygmatowi cyklu rocznego. Relacja ta prowadzi do analogii pomiędzy porami roku a etapami egzystencji człowieka: wiosna - młodość, lato — etap życia dojrzałego, dorosłość, jesień — starość, zima — śmierćc ${ }^{19}$. W epitafiach opisywana konceptualizacja pojawia się zazwyczaj na mogiłach zmarłych przedwcześnie. Realizuje ją grupa nominalna „wiosna życia”, która oznacza czas zgonu. Takie połączenie modeluje obraz egzystencji, ukazując ją jako krótką, gdyż — zgodnie z naturalistyczną analogią — nie odbyła ona pełnego cyklu:

\author{
Wezwałeś Go Panie \\ W wiośnie życia \\ (Tymowa, pow. brzeski) \\ Marcinek \\ I Mareczek \\ Zm. w 1-szej \\ Wiośnie życia \\ (Górki, pow. mielecki)
}

W wypadku nawiązań do cyklu rocznego funkcję domeny podstawowej pełni pojęcie życia, natomiast domeny docelowej — zmienność pór roku. Omawiana metafora jest najsilniej związana z ludowym postrzeganiem świata. U jej podstaw leży kluczowe dla światopoglądu społeczności wiejskiej „nieprzeparte uczucie jedności ze wszechświatem"20. Rezultat tego przekonania stanowi głęboko zakorzeniona w świadomości mieszkańców wsi wizja kosmosu jako organizmu żywego, którego nieodłącznym elementem jest człowiek. Ów intymny związek pomiędzy światem a ludźmi realizuje się we wszelkich sferach życia oraz działalności człowieka. Jego przejawem jest powiązanie ładu kosmicznego z życiem ludzkim, dzięki czemu ten pierwszy staje się wyznaczni-

\footnotetext{
wyznaczono następujące odcinki czasowe: „przede dniem, świt, wschód słońca, rano, przedpołudnie, południe, popołudnie, odwieczerz, zachód słońca, zmierzch, wieczór, noc, północ, głęboka (głucha) noc" (zob. K. Moszyński, Kultura ludowa Stowian, t. 2: Kultura duchowa, cz. 1, Warszawa 1967, s. 131).

${ }^{19}$ Odzwierciedleniem tej analogii są obecne w polszczyźnie metafory: „jesień życia”, „wiosna życia”.

${ }^{20}$ K. Moszyński, dz. cyt., s. 16.
} 
kiem rytmu ludzkiej egzystencji ${ }^{21}$. Taki sposób myślenia prowadzi do przeświadczenia, że życie człowieka, na które składają się między innymi praca oraz doroczne obrzędy, wynika z regularnie następujących cyklów przyrod ${ }^{22}$.

Metaforą życia jako cyklu rocznego posługuje się epitafium pochodzące z nekropolii w Wojniczu. Pierwsze zdanie przywołanej inskrypcji zawiera eksplikację metafory życia jako cyklu rocznego. Pozostała część nagrobka ogranicza się do konstatacji na temat ostatniego momentu życia ludzkiego - śmierci, której przenośnią jest zima. Epitafium informuje o możliwości odwrócenia naturalnego porządku, przez co ukazuje życie jako zbyt krótkie, a śmierć — jako przedwczesną:

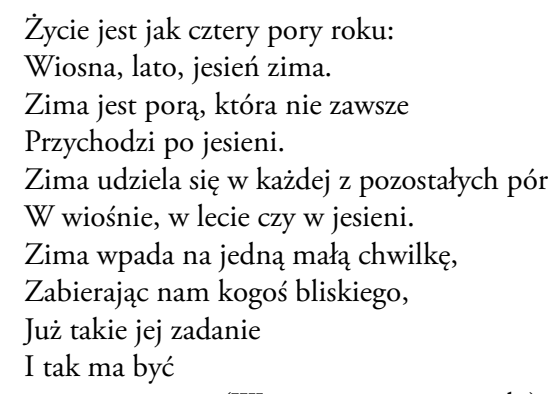

(Wojnicz, pow. tarnowski)

Prymarne znaczenie czasu, którego obraz utrwalony został w inskrypcjach, koncentruje się zatem wokół ludzkiego życia. W ten sposób pierwotna, słownikowa eksplikacja owego terminu oznaczająca „nieprzerwany ciąg chwil, trwania” ${ }^{23}$ schodzi na dalszy plan, a pierwotnym staje się pojmowanie czasu jako „wyodrębnionego okresu, wyodrębnionej pory, gdy coś jest wykonywane lub coś się dzieje"24. Tym przedziałem czasowym, o którym mowa w zdaniu definicyjnym, jest właśnie ludzka egzystencja, rozpięta pomiędzy narodzinami a śmiercią. Na kategorię życia jako szczególnego okresu nakłada się schemat rytmu dobowego czy — w szerszej perspektywie — cyklu rocznego. Taki sposób postrzegania czasu podkreśla jedność człowieka z przyrodą. Zgodnie z obrazem utrwalonym w inskrypcjach człowiek staje się jej integralną częścią, podlegającą tym samym prawom, co natura, a więc również poddaje się jej rytmowi. Należy jednak podkreślić, że w przeciwieństwie do rytmiczności, powtarzalności zmian zachodzących w przyrodzie, wyrażanej przy pomocy zarówno cyklu dobowego, jak i rocznego, życie ludzkie jako szczególny okres ma charakter nieodwracalny. Brak w nim powtarzalności charakterystycznej dla świata przyrody. Co więcej, łatwo zauważalne

${ }^{21} \mathrm{O}$ obrzędach cyklu rocznego i ich związku ze śmiercią zob. A. Krawczyk-Tyrpa, Tabu w dialektach polskich, Bydgoszcz 2001, s. 80. Autorka wskazała, że stałe punkty cyklu rocznego mogą służyć wyrażeniu zapowiedzi rychłej śmierci.

${ }^{22}$ J. Bartmiński, dz. cyt., s. 136.

${ }^{23}$ Stownik jezyka polskiego, s. 330.

${ }^{24}$ Tamże, s. 330. 
jest wartościowanie wynikające $\mathrm{z}$ istnienia owego porządku. Poszczególne etapy tych zmian podlegają ścisłej aksjologizacji. Wiosna i lato, będące w cyklu rocznym synonimami dzieciństwa i młodości, oceniane są pozytywnie. Podobnie jest w wypadku światła. Przebywanie w jego blasku, stanowiące metaforę życia, budzi dodatnie konotacje. Zdecydowanie negatywne skojarzenia wywołuje ciemność (cykl dobowy) oraz zima (cykl roczny) jako substytuty śmierci.

Jak już zauważono, epitafia posługujące się metaforą opartą na skojarzeniu z cyklem dobowym i rocznym, stanowią w badanym materiale dość liczną grupę. Ich popularność tłumaczyć można charakterystycznym dla społeczności wiejskiej sposobem postrzegania i kategoryzowania rzeczywistości. Ujawnia on typową dla nich skłonność do werbalizowania zjawisk za pomocą atrybutów, pochodzących z rzeczywistości im znanej, a więc bliskiej i oswojonej. Taki sposób kategoryzacji rzeczywistości świadczy także o dostrzeganiu zmienności świata oraz świadomości, że owa cykliczność posiada istotny wpływ na ludzką egzystencję.

Małgorzata Herchel

The Linguistic-Cultural Image of the Time Based on Metaphors of Daily and Annual Cycle Included in Funeral Inscriptions of Village Cemeteries (Example of Selected Villages of Podkarpacie and Malopolska Regions)

Summary

The deceased person, whose presence is constituted in funeral inscriptions by presentation of his name, surname and other information such as his achievements, is a crucial component of this sort of texts. The time seems to appear as equally important element of the inscriptions, which is a result of the fact that the existence of the dead person is immersed in the real historical time. Its linguistic image included in folk funeral inscriptions creates multivariate occurrence. Numerous groups of inscriptions use metaphors connected with the daily and annual cycle. These inscriptions significantly create the linguistic image of life and death and express its typical folk notion.

Słowa kluczowe: inskrypcja nagrobna, językowy obraz świata, językowy obraz czasu, kultura ludowa Keywords: funeral inscription, linguistic image of the word, linguistic image of the time, folk culture 